\title{
FEKALNA TRANSPLANTACIJA
}

\author{
Aida KRKIĆ DROBIĆ, mag. med. techn. \\ Škola za medicinske sestre Vinogradska \\ Vinogradska cesta 29, Zagreb \\ akrkic0@gmail.com
}

\section{SAŽETAK}

Transplantacija mikrobiota iz fecesa (eng. Fecal Microbiota Transplant, FMT) proces je transplantacije infuzije bakterija iz stolice zdravog donora do primatelja s bolešću za koju se vjeruje da je povezana s nezdravim crijevnim mikrobiomom. Unos kapsuliranih bakterija zdrave osobe provodi se endoskopom, nazogastričnom sondom ili oralno pomoću kapsule. Taj je pristup prilično uspješan za liječenje infekcija uzrokovanih bakterijom Clostridium difficile, koja uzrokuje po život opasne proljeve. U literature je nađeno da je kompatibilnost između donora i primatelja znatno važnija nego što se zasada smatra, pa bi takvim pristupom primjena FMT-a vjerojatno bila uspješna i u liječenju drugih crijevnih oboljenja.

Pokazalo se da je „bakterijska kompatibilnost“ donora i primatelja izuzetno važna - transplantat jednog donora imao je različite učinke kod triju različitih bolesnika. Da bi se minimalizirao rizik od infekcije ili prijenosa drugih bolesti, potencijalni donori podvrgavaju se rigoroznom pregledu, uključujući temeljito uzimanje anamneze, serološke testove i fekalne testove na parazitske, virološke i bakterijske patogene. Iako postoje neke razlike među institucijama, doneseni su prihvaćeni protokoli za skrining donora. Uz banke fecesa, koje pružaju univerzalni fekalni materijal za korištenje, koji je visoko pregledan i katalogiziran, mogu se prevladati prepreke poput troškova i dostupnosti, što omogućuje pojednostavljivanje istraživanja i liječenja. Uz to, uporaba kapsule FMT-a povezuje se s poboljšanom pogodnošću, smanjenom nevoljkošću bolesnika i pojednostavljenom proceduralnom pripremom. Kako bi se održala sigurnost bolesnika i prikladna uporaba FMT-a, očekuje se pojavljivanje standardiziranih protokola za probir davatelja, pripremu stolice, načina isporuke i indikacija primatelja za liječenje.

Ključne riječi: transplantacija mikrobiota iz fecesa, Clostridium difficile infekcija, kolonoskopija.

\section{UVOD - povijesni pregled primjene fekalne transplantacije}

Iako je novi pristup liječenja infekcije $C$. difficile u zapadnoj medicini, FMT je opisana prije 1700 godina. Bio je to drevni kineski istraživač iz 4. stoljeća pod imenom Ge Hong, koji se prvi koristio onim što se nazivalo 'žutom juhom' za liječenje svojih bolesnika s teškim proljevom. 'Juha' se primjenjivala oralno, što je vjerojatno objasnilo neuspjeh tehnike da postane široko poznata. Veterinari su također znali za mogućnost upotrebe stolice kao terapijskog načina davanja oralnim ili rektalnim putem iz 17. stoljeća. Njemački vojnici koristili su se devinom stolicom za liječenje bakterijske dizenterije tijekom Drugog svjetskog rata. Tehnika je privukla pažnju i u našem vremenu nakon što su je objavili Eiseman i suradnici u izvješću o njegovu liječenju bolesnika $\mathrm{s}$ dijarejom liječenom $\mathrm{s}$ antibioticima, a upotrebom postupka FMT putem retencijskih klistira. Bolesnici su se brzo i dobro oporavili od 
proljeva. Bilo je to 1958. godine (Thomas, 2021).Godine 1958. Eiseman i kolege izvijestili su o seriji slučajeva od četiri bolesnika s pseudomembranoznim enterokolitisom koji su odmah izliječeni "jednostavnom terapijskom mjerom", fekalnim klistirima. Stanje je gotovo sigurno uzrokovano Clostridium difficile, bakterijom povezanom s pseudomembranskim kolitisom. Međutim, povezanost s upotrebom antibiotika bila je dobro prepoznata ranije, a postupanje s fekalnim klistirima pretpostavljalo se da „ponovno uspostavlja prirodnu ravnotežu” ponovnim uvođenjem bakterija, virusa i bakteriofaga koji se normalno nalaze $\mathrm{u}$ debelom crijevu. Pseudomembranozni kolitis 1950-ih bio je stravična bolest s gotovo $75 \%$ smrtnosti. Stopa smrtnosti unutar 30 dana od kirurškog izrezivanja debelog crijeva, koja je i dalje trenutni standard njege zbog teško komplicirane infekcije $C$. difficile (CDI), rezistentne na antibiotike, i dalje iznosi približno 50\% (Khoruts, 2017).

Prvi dokumentirani slučaj potvrđenog CDI-a liječenog FMT-om izvijestili su 1983. godine Schwan i sur. U ovom je slučaju terapija primijenjena kod 65-godišnjakinje, a rezultirala je brzom i potpunom normalizacijom rada crijeva. Tijekom praćenja devet mjeseci kasnije, bolesnica je ostala asimptomatski. Godine 1989. Tvede \& RaskMadsen izvijestili su o liječenju bolesnika s kroničnim relapsom proljeva uzrokovanih $C$. difficile liječenim rektalnim ukapavanjem homolognih fekalija (jedan bolesnik) ili smjesom deset različitih fakultativnih ili obveznih anaerobnih bakterijskih vrsta razrijeđenih u sterilnoj fiziološkoj otopini (pet bolesnika). Oba terapijska pristupa rezultirala su trenutnim gubitkom $C$. difficile i njezina toksina iz stolice, obnavljanjem normalnog rada crijeva unutar dvadeset $\mathrm{i}$ četiri sata $\mathrm{i}$ nestankom abdominalnih simptoma. Nakon tih početnih demonstracija učinkovitosti, uporaba FMT-a nastavila se širiti (Rogers, 2013).

\section{FIZIOLOGIJA}

Mikroorganizmi ulaze u najbrojnije i najrazličitije organizme na Zemlji. Većina Zemljine biomase, ukupne mase živih bića, je mikrobna. Pod izrazom mikroorganizam obuhvaćamo sve organizme koji su presitni da bi bili vidljivi golim okom, već je potrebna pomoć mikroskopa. Te jednostavne organizme klasificiramo kao bakterije (Bacteria), arheje (Archaea) i eukarije (Eukarya).

Mikrobiota je skup mikroorganizama prisutan u definiranom okolišu.

Mikrobiom: ovaj pojam odnosi se na cijelo stanište, uključujući mikroorganizme (bakterije, arheje, niže i više eukarije), njihove genome (tj. gene) i okolišne čimbenike. Ta definicija temelji se na onoj 'bioma', tj. biotičkim i abiotičkim čimbenicima određenog okoliša (Pajić, 2017).

Ljudske mikrobiote sastoje od mnoštva mikroorganizama, uključujući eukarije, arheje i bakterije. Ljudskih stanica u našem tijelu ima 
oko 10 trilijuna $\mathrm{u}$ usporedbi $\mathrm{s}$ mikroorganizmima koji broje 100 trilijuna. Također u usporedbi broja ljudskih gena $\mathrm{s}$ mikrobnim genima, ljudski genom broji oko 20000 gena dok mikroorganizmi od 2 do 20 milijuna gena. Bakterija u ljudskom tijelu u prosjeku ima deset puta više nego ljudskih stanica (10\% ljudskih stanica), a bakterijskih gena ima 100 do 1000 puta više nego što ih je prisutno u ljudskom genomu (0.1-1\% ljudskih gena). Kada uspoređujemo koliko se ljudske jedinke međusobno razlikuju po svojim ljudskim genima i genima mikrobioma, dobivamo $99.99 \%$ sličnosti s drugim ljudima kada gledamo naš DNA, no naši mikrobiomi dijele samo $10 \%$ sličnosti s drugima.

Ljudski mikrobiom se sastoji od brojnih mikrobiota, poput mikrobiota kože (mikroorganizmi koji naseljavaju površinu i dublje slojeve kože), usne šupljine (oralna) (mikroorganizmi koji naseljavaju sluznicu usne šupljine), vagine/penisa te gastrointestinalnog trakta (nadalje GIT) prethodno znane pod nazivom GIT flora i drugih (Qin, 2010).

Radi boljeg razumijevanja ravnoteže i neravnoteže mikrobioma, potrebno je definirati pojmove eubioze i disbioze. Eubioza jest ravnotežno stanje mikrobnog ekosustava, dok disbioza predstavlja neravnotežu istog. Većina istraživanja crijevnog mikrobioma, uključujući pionirski rad Human Microbiome Project-a za karakterizaciju mikrobioma $\mathrm{u}$ zdravih osoba, usredotočila se na debelo crijevo i stolicu, te raznoliku mikrofloru ovog distalnog crijeva. Međutim, gastrointestinalni sustav sigurno nije ograničen na distalno crijevo, a važno je napomenuti da se čini da se bakterijski sastav jednjaka, želuca i tankog crijeva značajno razlikuje od sastava debelog crijeva, kako u raznolikosti, tako I u razlici koji mikrobi prevladavaju. $\mathrm{Na}$ primjer, u jednjaku se čini da su ograničena raznolikost i prisutnost nekoliko rodova, poput streptokoka, povezani sa zdravljem, dok nizak $\mathrm{pH}$ želuca stvara okruženje koje odabire za ograničeni broj bakterija otpornih na kiseline. Osim toga, čini se da u debelom crijevu postoje razlike između mikrobnih vrsta pronađenih u lumenu (stolici) i onih pronađenih u uzorcima tkiva sluznice. Zdrava mikrobiota distalnih crijeva čovjeka vrlo je raznolika, vjerojatno obuhvaća preko 1000 vrsta. Možda postoji određeni zajednički „mikrobiom u srži”, kojim se čini da u zdravih osoba dominiraju vrste Firmicutes i Bacteriodetes, zatim Actinobacteria i Verrucomicrobia. Međutim, relativni udjeli i prisutne vrste $u$ pojedinim mikrobnim zajednicama mogu se drastično razlikovati. Mikrobiota nudi brojne prednosti za domaćina, kroz niz fizioloških funkcija poput jačanja integriteta crijeva ili oblikovanja crijevnog epitela, sakupljanja energije, zaštite od patogena i reguliranja imuniteta domaćina.

Međutim, postoji mogućnost da se ovi mehanizmi naruše kao rezultat promijenjenog 
mikrobnog sastava, poznatog kao disbioza. Čini se da dob, imunološki sustav domaćina, genetika domaćina, prehrana i upotreba antibiotika modificiraju crijevni mikrobiom (Tuddenham, 2015).

Sve je veći interes za razumijevanje uloge mikrobioma ljudskog crijeva u iskorištavanju terapijskog potencijala njegove manipulacije. Mnoga ispitivanja pokazala su da bogatstvo i raznolikost bakterijskih vrsta u ljudskim crijevima mogu biti pokazatelj zdravlja. Uz to, prisutnost određenih skupina bakterija može pružiti zdravstvene prednosti. Dokazano je da određeni mikrobi pojačavaju metabolizam, imunološki sustav, otpornost na rak, endokrini odgovor i rad mozga. Neke bakterijske vrste, povezane s ovim prednostima uključuju: Bacteroides, Bifidobacterium, Clostridium clusters XIVa / IV i Lactobacillus. Čini se da mikrobiom crijeva ostaje $\mathrm{s}$ vremenom relativno elastičan, međutim, upotreba antibiotika, putovanja i bolest mogu dovesti do njegovih varijacija. Studije su pokazale sposobnost crijevnog mikrobioma da se oporavi od ozljeda, međutim, kontinuirani poremećaj može dovesti do gubitka te elastičnosti i može imati implikacije na ljudsko zdravlje (Gupta, 2016).

\section{PATOFIZIOLOGIJA}

\subsection{Infekcija Clostridium difficile (CDI)}

Clostridium difficile je anaerobna sporogena bakterija prisutna u zemlji, vodi i probavnom sustavu životinja, zdrave djece i odraslih ljudi. Sve češća upotreba antibiotika, kojom se narušava normalni crijevni makrobiom te omogućava pojačano umnožavanje. Toksikogeni sojevi $C$. difficile oštećuju epitelni sloj debelog crijeva i tako uzrokuju kolitis, koji se manifestira kao klinički blaža ili teža akutna ili prudužena dijarejalna bolest. Upalni oblici bolesti, praćeni hipotenzijom, šokom, ileusom ili toksičnim megalokolonom susreću se u 3 $5 \%$ bolesnika i imaju smrtnost do $70 \%$. Zbog izrazite otpornosti spora na fizikalne uvjete okoline (u okolišu ostaje viabilna do pet mjeseci) i na alkoholne dezinficijense, te se vrlo često nalazi u prostorima zdravstvenih ustanova kao i na rukama zdravstvenih djelatnika, vodeća je bolnička infekcija i postaje sve virulentnija i ozbiljnija epidemija (CJI Infektološki glasnik, 2018). Ukupno 15\% - 25\% svih slučajeva proljeva povezanog $\mathrm{s}$ antibioticima (AAD) proizlazi iz CDI-a. Vjerojatnost da je $C$. difficile uzrok AAD raste s težinom bolesti, dosežući $95 \%-100 \%$ među bolesnicima $\mathrm{s}$ dokumentiranim PMC-om (pseudomembranozni kolitis) povezanim $\mathrm{s}$ antibioticima. Točna dijagnoza na početku bolesti važna je za uspješno liječenje CDI (Bartlett, 2008).

Glavni čimbenici rizika za CDI debelog crijeva su izloženost antibioticima, hospitalizacija i poodmakla dob. Prethodna uporaba antibiotika prevladavajući je faktor rizika za stjecanje CDI. 
Neki antibiotici, posebno klindamicin, cefalosporini i $\beta$-laktami povezani su $\mathrm{s}$ relativno visokim rizikom od CDI. Upotreba kombinirane antibiotske terapije i dugoročno primanje antibiotske terapije također su faktori rizika. Međutim, CDI se može pojaviti čak i kod bolesnika izloženih kratkotrajnim profilaktičkim dozama antibiotika. Prevalencija spora $C$. difficile u okolišu relativno je velika među bolnicama i ustanovama za dugotrajnu njegu. Stoga ne čudi da bolesnici u tim ustanovama imaju veće stope kolonizacije C. difficile (stopa kolonizacije, $\quad 10 \% \quad-25 \% \quad$ među hospitaliziranim bolesnicima i $4 \%-20 \%$ među korisnicima ustanova za dugotrajnu njegu) od zdravih odraslih osoba $\mathrm{u}$ općoj populaciji (stopa kolonizacije, 2\%-3\%). Boravak u jedinici intenzivne njege, produljeni boravak $u$ bolnici i, možda, fizička blizina zaražene osobe također su zabilježeni kao faktori rizika za CDI. Uz to, niz drugih čimbenika utječe na osjetljivost bolesnika na CDI. Stariji bolesnici pod znatno su većim rizikom, a stope bolesti kod bolesnika iznad 65 godina čak su 20 puta veće od onih kod mlađih bolesnika. Ostali čimbenici koji povećavaju rizik uključuju ozbiljnost osnovne bolesti, nekirurški gastrointestinalni postupci i, možda, upotreba antiulkusnih lijekova. Bolesnici koji imaju poremećen imunološki sustav ili loš imunološki odgovor na toksine $C$. difficile također su u povećanom riziku. Prisutnost ili odsutnost tih čimbenika rizika, posebno upotreba antibiotika i nedavnim boravkom $\mathrm{u}$ bolnici, treba uzeti u obzir $\mathrm{u}$ diferencijalnoj dijagnozi dijareje. Konkretno, bolesnici $\mathrm{s}$ dijarejom koja nastaje oko 72 sata nakon prijama u bolnicu i koji primaju antibiotike imaju mnogo veću vjerojatnost da imaju CDI od infekcije alternativnim enteropategonom. Budući da $C$. difficile može prouzročiti proljev u ambulantnih bolesnika (iako mnogo nižom stopom nego što uzrokuje proljev $u$ stacionarnih bolesnika), bolesnici pri prijamu mogu imati uzorke stolice pozitivne na $C$. difficile (Bartlett, 2008).

\subsubsection{Klinička slika}

Iako je za konačnu dijagnozu obično potrebna laboratorijska potvrda prisutnosti $C$. difficile toksina, nekoliko kliničkih čimbenika može pomoći usmjeriti dijagnozu i pomoći $u$ dijagnosticiranju dijareje zbog CDI. Najčešći klinički simptom CDI-a je proljev (dijareja) povezan s prethodnim uzimanjem antibiotika. Proljev se obično javlja tijekom ili nedugo nakon primanja antibiotske terapije, ali može se dogoditi od nekoliko dana nakon početka antibiotske terapije pa sve do 8 tjedana nakon prekida terapijen. Za blagu do umjerenu bolest, dijareja je obično jedini simptom, kod bolesnika koji imaju do, ali obično znatno manje od deset stolica dnevno. Stolice su obično vodenaste, karakterističnog smrdljivog 
mirisa. Ostale kliničke značajke u skladu s CDI uključuju grčeve u trbuhu, vrućicu, leukocitozu i hipoalbuminemiju. Sve u svemu, vrućica se javlja $\mathrm{u} \sim 28 \%$ slučajeva, leukocitoza $\mathrm{u} \sim 50 \%$, a bolovi u trbuhu $\mathrm{u} \sim 22 \%$ [20]. Groznica i leukocitoza mogu biti ozbiljni u mnogih bolesnika, s temperaturama koje povremeno dosežu $40^{\circ} \mathrm{C}$. Bolovi u trbuhu, kada se pojave, obično su lokalizirani u donjim kvadrantima. Hipoalbuminemija je rezultat velikih gubitaka proteina koji se mogu pripisati istjecanju albumina i može se javiti rano u toku bolesti. Dokazi o kolitisu uključuju vrućicu, grčeve, leukocitozu, prisutnost leukocita $u$ stolici i upalu debelog crijeva vizualiziranu endoskopijom (za pseudomembrane) ili CTom (za zadebljanje stijenke debelog crijeva). Teška bolest može uzrokovati paralitički ileus koji se može razviti u otrovni megakolon, uz mučninu, povraćanje, dehidraciju, letargiju ili tahikardiju, uz povišenu temperaturu i bolove $\mathrm{u}$ trbuhu. Treba imati na umu da u rijetkim slučajevima proljev može biti odsutan u bolesnika s teškim CDI-jem. Ovakav slučaj događa se kada infekcija uzrokuje paralitički ileus, sprečavajući prolazak stolice. To je možda najčešće kod postoperativnih bolesnika koji narkotike primaju zbog bolova. Stoga bi simptomi poput inače neobjašnjive vrućice, leukocitoze i bolova u trbuhu kod bolesnika $\mathrm{s}$ nedavnom izloženošću antibioticima trebali potaknuti sumnju na CDI, čak i ako nema proljeva (Bartlett, 2008.).
2.1.2. Nove smjernice liječenja infekcije Clostridium difficile

Od strane IDSA i Društva za zdravstvenu epidemiologiju Amerike (SHEA) objavili su u časopisu Clinical Infectious Diseases ažurirane smjernice o dijagnozi i liječenju Clostridium difficile (C. diff.) Dijagnoza i liječenje $C$. diff. značajno se razvio od posljednjih smjernica objavljenih 2010. godine. CDI dijagnosticira se na temelju povijesti bolesti pacijenta, znakova i simptoma, u kombinaciji $\mathrm{s}$ rezultatima ispitivanja. Optimalna metoda za laboratorijsku dijagnozu C. diff. je predmet rasprave i ovisi o tome koliko su pažljivo odabrani bolesnici za testiranje. Ažurirane smjernice preporučuju samo testiranje bolesnika s novom pojavom (recidivima) i neobjašnjivim proljevima (tri ili više neoblikovanih stolica u 24 sata). Iako su imunološki testovi bili najčešća dijagnostika koja se ranije koristila, molekularno testiranje - koje ima svoje prednosti i nedostatke - danas koristi više od $70 \%$ bolničkih laboratorija. Molekularni testovi mogu pomoći $u$ isključivanju C. diff. infekcije, kao i smanjiti prijenos otkrivanjem $C$. diff. kolonizacija u bolesnika s proljevom zbog drugih uzroka. No budući da su vrlo osjetljivi, i mogu dovesti do prekomjerne dijagnoze, kada ne postoje unaprijed dogovoreni institucionalni kriteriji koji ograničavaju testiranje bolesnika sa značajnim neobjašnjivim proljevom od tri ili više neoblikovanih stolica u 24 sata, smjernice 
Nastavnička revija 2 (2021) 1, 47-67

preporučuju $C$. diff. uobičajeni test antigena i test toksina u stolici (kao što je imunološki test) kao dio postupka ispitivanja u dva ili tri koraka. Smjernice uključuju nove preporuke za liječenje kada je to potrebno, uključujući: Vankomicin ili fidaksomicin - Antibiotici vankomicin ili fidaksomicin trebaju se koristiti za početno liječenje čak i blage $C$. diff. (umjesto metronidazola, što su prethodne smjernice preporučivale kao prvu terapiju). Istraživanja pokazuju da su stope izlječenja veće za vankomicin i fidaksomicin nego za metronidazol.

Transplantacija fekalne mikrobiote (FMT) Smjernice preporučuju FMT za liječenje osoba s dva ili više recidiva $C$. diff. i kod kojih tradicionalno liječenje antibioticima nije uspjelo. FMT uključuje prijenos fekalnih bakterija iz stolice zdrave osobe u crijeva osobe $\mathrm{s}$ ponavljajućim $C$. diff., radi nadopunjavanja dobrih bakterija i suzbijanja bakterija koje uzrokuju bolest. Smjernice uključuju prijedloge za sprečavanje širenja $C$. diff., uključujući izoliranje zaraženih bolesnika i osiguravanje da zdravstveni djelatnici i posjetitelji koriste rukavice i zaštitne mantile, ali također pozivaju na veću pozornost na upotrebi antibiotika kako bi se smanjila neopravdana upotreba lijekova. U Tablici 1. su prikazane ažurirane smjenice liječenja CDI. U slučajevima blage I srednje do teške kliničke slike CDI, koristi se antibiotsko liječenje Vankomicinom ili fidaksomicinom. U slučajevu recidivirajućih CDI, preporuka je postupak Fekalne transplantacije (https://sheaonline.org/index.php/journal-news/websitehighlights/572-new-clostridium-difficileguidelines). 


\section{IDSA/SHEA guidelines update $02 / 2018$}

\begin{tabular}{|c|c|c|c|}
\hline & \multicolumn{3}{|c|}{ Klinička težina CDI } \\
\hline Broj CDI epizode & Blaga/srednje teška & Teška & Fulminantna \\
\hline 1. & \multirow{3}{*}{\multicolumn{2}{|c|}{$\begin{array}{l}\text { Vankomicin P.O. } \\
\text { (ili fidaksomicin) }\end{array}$}} & $\begin{array}{c}\text { Vankomicin P.O. } \\
+ \\
\text { Metronidazol I.V. }\end{array}$ \\
\hline 2. & & & $\begin{array}{c}+/- \\
\text { Vankomicin klizma }\end{array}$ \\
\hline & & & $+1-$ \\
\hline$\geq 3$. & \multicolumn{2}{|c|}{$\begin{array}{c}\text { Vankomicin P.O. } \\
\text { ili fidaksomicin } \\
\text { + Padajuća doza vankomicina P.O. } \\
\text { ili } \\
\text { + Transplantacija fekalne flore }\end{array}$} & $\begin{array}{c}\text { Liječenje u JIM } \\
+/- \\
\text { Kirurgija } \\
\text { (loop ileostomija) } \\
+/- \\
\text { Transplantacija } \\
\text { fekalne flore }\end{array}$ \\
\hline
\end{tabular}

Tablica 1. Ažurirane smjernice IDSA/SHEA 02/2018 za liječenje CDI

\subsection{Transplantacija fekalne mikrobiote}

Transplantacija fekalne mikrobiote (FMT) je primjena otopine fekalne tvari od donora $\mathrm{u}$ crijevni trakt primatelja kako bi se izravno promijenio mikrobni sastav primatelja i donijelo zdravstvenu korist. Transplantacija mikrobiota iz fecesa (eng. Fecal Microbiota Transplant, FMT) proces je transplantacije infuzije bakterija iz stolice zdravog donora do primatelja s bolešću za koju se vjeruje da je povezana $\mathrm{s}$ nezdravim crijevnim mikrobiomom. Proces obično uključuje prvo odabir donora bez obiteljske povijesti autoimunih, metaboličkih i zloćudnih bolesti te probir na potencijalne patogene. Feces se zatim priprema miješanjem $\mathrm{s}$ vodom ili normalnom fiziološkom otopinom, nakon čega slijedi korak filtracije kako bi se uklonile sve čestice. Smjesa se može primijeniti kroz nazogastričnu sondu, nazojejunalnu sondu, ezofagogastroduodenoskopiju, kolonoskopiju ili retencijsku klizmu. Većina kliničkih iskustava s FMT-om izvedena je iz liječenja ponovljene ili rezistentne infekcije Clostridium difficile (CDI) (Gupta, 2016). 
Nastavnička revija 2 (2021) 1, 47-67

\subsection{Dodatne dijagnoze}

Osim infekcije bakterijom C. difficile, najvažnije dodatne dijagnoze koje je moguće liječiti ovom metodom: upalne bolesti crijeva, sindrom iritabilnog crijeva i metabolički sindrom.

2.4.1. Upalne bolesti crijeva (eng. Inflammatory bowel disease)

IBD je crijevni poremećaj koji uključuje ulcerozni kolitis (UC) i Crohnovu bolest (CD). IBD je karakteriziran kroničnom upalom gastrointestinalnog trakta i ima cikličku prirodu progresije i remisije bolesti. Tijekom razdoblja aktivnosti bolesti (kolokvijalno nazvane bljeskovi), bolesnici mogu imati proljev, mučninu, gubitak težine, gubitak apetita, vrućicu i bolove u trbuhu. Precizna patofiziologija je nepoznata, ali uzrok je višestruki, zbog neravnoteže u crijevnom mikrobiomu, crijevnom epitelu i imunološkom sustavu kod genetski osjetljivih osoba. Pretpostavlja se da se IBD pojavljuje zbog kontinuirane neprikladne antigene stimulacije limfnog tkiva povezanog sa sluznicom crijeva komensalnim mikrobima. Disbioza crijeva nedavno se smatra mogućim patološkim doprinosom razvoju IBD-a. Ovu ideju potkrepljuju zapažanja da antibiotici poput amoksicilina / klavulanske kiseline i rifaksimina mogu smanjiti crijevnu upalu i izazvati remisiju kod nekih bolesnika. Razna ispitivanja okarakterizirala su mikrobiom IBDa i utvrdila sveukupno smanjenu bakterijsku raznolikost. Sveukupno je utvrđeno da mikrobiom IBD potiče upalu, što ukazuje na povećani oksidativni stres I povećano lučenje toksina. Nedavno je pokazano da je transplantacija fekalnih ekosustava s bolesnika s UC na miševe bez klica povećala osjetljivost

na kolitis, podržavajući tako upotrebu modifikacije mikrobiota za liječenje UC. Dokazi koji povezuju mikrobnu disbiozu crijeva s IBD-om doveli su do istraživanja FMT-a kao terapije bolesti. Nedavni sustavni pregled i metaanalize proučavali su 18 studija, uključujući 122 bolesnika s IBD-om liječenih FMT-om, i utvrdili su ukupne kliničke stope remisije od 36,2\% (nakon što su serije slučajeva uklonjene radi kontrole radi pristranosti u objavljivanju). Analize podskupina pokazale su da je stopa kliničke remisije u bolesnika s UC bila $22 \%$, dok su mlađi bolesnici (u dobi od 7 do 20 godina) imali stopu od 64,1\%, a bolesnici s CD-om od 60,5\%. Čini se da je FMT možda učinkovitiji za ChD i mlađe bolesnike nego za UC infekciju, međutim teško je donijeti konačne zaključke zbog male veličine uzorka, kratkog vremena praćenja i heterogenih rezultata. Ovi različiti rezultati mogu biti posljedica razlika u načinima primjene, donorima stolice, rasporedu doziranja ili istodobnim terapijama. Iako tijekom kratkotrajnog praćenja bolesnika s IBD-om liječenih FMT-om nisu zabilježeni ozbiljni štetni događaji, izvješteno je da su neki razvili vrućicu, hladnoću, nadutost, nadimanje, povraćanje, proljev i osjetljivost $u$ trbuhu. 
A.Krkić Drobić, Fekalna transplantacija

Također, bilo je izvještaja o pogoršanju stanja bolesnika nakon FMT-a. Stoga FMT treba koristiti s oprezom dok se ne završe visokokvalitetna, adekvatno pokrenuta ispitivanja koja procjenjuju njegovu djelotvornost kod IBD-a. Međutim, jasno je da

FMT nije toliko učinkovit kod IBD-a kao kod CDI-a (koji ima visoku stopu izliječenja bez obzira na metodu), a to je vjerojatno zbog multifaktorske patofiziologije IBD-a.

2.4.2. Funkcionalni gastrointestinalni poremećaji

Funkcionalni gastrointestinalni poremećaji (FGID) najčešće su dijagnosticirane gastrointestinalne bolesti na zapadu. Karakterizira ih prisutnost gastrointestinalnih simptoma uz odsutnost bilo kakvih anatomskih ili biokemijskih abnormalnosti koje se mogu identificirati. Sindrom iritabilnog crijeva (IBS) najrasprostranjeniji je oblik FGID-a i pogađa $10-15 \%$ populacije. IBS ima štetan utjecaj na kvalitetu života bolesnika i stavlja ekonomsko opterećenje na zdravstveni sustav. Postoje četiri podvrste IBS-a, temeljene na dominantnim simptomima koje bolesnik doživljava. IBS-D prevladava proljev, IBS-C prevladava zatvor, IBS-M mješoviti proljev i zatvor, a IBS-U je za one koji nisu podtipirani. Patofiziologija nije dobro definirana, ali uključuje visceralnu preosjetljivost, izmijenjenu funkciju barijere $\mathrm{i}$ promijenjenu gastrointestinalnu pokretljivost. Te promjene mogu biti povezane $\mathrm{s}$ promjenama $\mathrm{u}$ mikrobioti crijeva. Objavljene su male, ograničene serije slučajeva koje pokazuju upotrebu FMT-a za liječenje FGID-a. Jedna studija primijenila je FMT na 45 bolesnika s kroničnom opstipacijom kolonoskopijom i

naknadnom retencijskom klizmom, te je utvrđeno da $89 \%$ pacijenata ima trenutno ublažavanje simptoma, dok $60 \%$ ima trajnu korist u 9-19 mjeseci. Čini se da FMT može imati terapeutski učinak na liječenje FGID-a, međutim, zaključci se ne mogu donijeti jer su dostupni podaci izuzetno ograničeni i podložni pristranosti. Treba provesti dobro osmišljena ispitivanja kako bi se utvrdilo postoji li doista veza između crijevne mikrobiote i FGID-a.

\subsubsection{Pretilost i metabolički sindrom}

Pretilost je poremećaj koji karakterizira pretjerano taloženje masnog tkiva. Metabolički sindrom karakterizira konstelacija znakova I simptoma kao što su pretilost, hipertenzija, dislipidemija i hiperglikemija koja povećava rizik za razvoj srčanih bolesti i dijabetesa melitusa. Nedavna istraživanja pokazuju da mikrobiom crijeva može biti uključena u patofiziologiju pretilosti. Uvidom $\mathrm{u}$ studije nađene su razlike u mikrobiomima crijeva u mršavih $\mathrm{i}$ pretilih osoba te su izvijestile o značajnim razlikama između njih dvoje. Nedavno je mala dvostruko slijepa, randomizirana, kontrolirana studija otkrila da 
su transplantacije fekalija s mršavih na pretile (s metaboličkim sindromom) rezultirale poboljšanom osjetljivošću na inzulin, povećanom raznolikošću crijeva i mikroba. Ova studija pokazuje načelni dokaz za buduće istraživanje FMT-a za liječenje pretilosti,

metaboličkog sindroma i dijabetesa melitusa. Suprotno tome, potencijal crijevnog mikrobioma da utječe na debljanje doveo je do prijedloga da se indeks tjelesne mase donora možda mora uzeti u obzir pri odabiru kandidata za darivatelje FMT-a (Gupta, 2016).

\subsubsection{Opis postupka}

Potrebno je dati odgovor na pitanje što je fekalna transplantacija: to je prijenos fekalne mikrobiote, odnosno oblik liječenja infuzijom tekućeg filtrata stolice zdravog donora $u$ crijevo primatelja, kako bi se normalizirala crijevna mikrobiota. Donori trebaju biti zdrave osobe kod kojih su isključene infektivne bolesti, gastrointestinalna, neurološka i metabolička oštećenja, ekspozicija antibioticima, kemoterapija i imunosupresivi u posljednja 3 mjeseca. Trebaju imati negativne testove krvi i stolice na brojne viruse i bakterije. Fekalni uzorak za transfer može se pripremiti kao svjež ili smrznut. Svježi se feces može upotrijebiti unutar šest sati od defekacije. Kako bi se sačuvale anaerobne bakterije, pohrana i priprema moraju biti što kratkotrajnije.

Postupak fekalne transplantacije sastoji se od preuzimanja uzorka od zdravog donora, nakon čega se smrzava i pohranjuje, te se zatim transferira osobi koja boluje od infekcije. Smrznuti fekalni materijal treba se pohraniti na $-80^{\circ} \mathrm{C}$, a onda na dan fekalne infuzije suspenzija stolice treba se zagrijati na $37^{\circ} \mathrm{C}$ kako bi se mogao transfer učiniti putem

gornjeg ili donjeg endoskopskog pristupa (Štimac, 2019).

Kako u svom radu kažu Joksimović i sur. (prama Šušnjar, 2019), analiza rezultata primjene FT pokazala je kako se na uzorku od 317 bolesnika s recidivirajućim infekcijama ovom bakterijom fekalna transplantacija pokazala uspješnom metodom liječenja u $92 \%$ slučajeva. U tim istraživanjima, $35 \%$ pacijenata primilo je FT putem klistira sa pozitivnim odgovorom od 95\%, 23\% bolesnika preko nazogastrične sonde sa terapeutskim odgovorom od $76 \%$, a $19 \%$ putem kolonoskopije, sa stopom odgovora od 89\% (Šušnjar, 2019: 34).

\subsubsection{Odabir i pregled davatelja stolice}

Odabir donora predstavlja temeljni izazov s obzirom na primjenu FMT programa širom svijeta. Do danas postoji široka rasprava u vezi s preferencijama odabira donora, treba li donor fecesa biti poznat bolesniku ili je poželjnije koristiti feces nesrodnog donora. Štoviše, u slučaju nesrodnog donora, fekalni materijal mogao bi se staviti u posebne banke fecesa koje pružaju podršku bolnici koja će izvoditi FMT. Idealan donor fecesa trebao bi biti zdrav 
A.Krkić Drobić, Fekalna transplantacija

volonter, bez čimbenika rizika za zarazne ili druge kronične bolesti i koji je spreman često „donirati” ako je potrebno. Nažalost, iako se uvjeti ne čine previše selektivnima, nije uvijek lako identificirati dovoljan broj donora kako bi se udovoljilo potrebama FMT programa.

Zapravo, podaci velike banke fecesa sugeriraju visoke stope odustajanja donora zbog velike obveze; nadalje, liječnici se često odriču FMTa zbog složenosti i troškova pregleda. Slijedom toga, za rješavanje ovih problema bilo bi primjereno provoditi neusmjereni program odabira donora. Stoga bi povezani donori trebali biti ograničeni samo u slučajevima preferencija bolesnika. Doista, neusmjereni donori smanjili su vjerojatnost zabrinutosti zbog povjerljivosti, a zatim su presudni za provedbu bankarstva $\mathrm{s}$ obzirom na laku dostupnost, sljedivost i smanjenje troškova pregleda.

Provjera potencijalnih donora sastoji se od dvije ključne točke, preliminarnog razgovora $\mathrm{i}$ laboratorijskog ispitivanja. Preliminarni intervju obično se provodi strukturiranim upitnikom koji je istražuje nekoliko čimbenika rizika kako bi se smanjio rizik od prenošenja infekcija ili negativnog profila crijevne mikrobiote. Medicinski intervju posebnu pažnju posvećuje upotrebi lijekova potencijalnih donora a koji mogu izmijeniti mikrobiotu crijeva, anamnezu ili rizična ponašanja zbog zaraznih bolesti i za poremećaje potencijalno povezane $\mathrm{s}$ poremećajem crijevne mikrobiote. Ovaj intervju nije obvezan, ali se može prilagoditi socio-kulturnom kontekstu potencijalnih donora. Na primjer, bilo bi poželjno pažljivo istražiti prehrambene navike potencijalnih donora iz zemlje u kojoj je konzumacija sirovog mesa i ribe široko rasprostranjena,

povećavajući tako rizik od prijenosa enteričkih patogena ili koji jedu egzotične životinje koje su potencijalni nositelji nepoznatih patogena; ili sezonske navike koje povećavaju rizik od zaraze crijevnim uzročnicima bolesti (npr. ljetni praznici i rizik od morske hrane loše kvalitete). Ti primjeri omogućuju razumijevanje kako je cilj razgovora rano presretanje potencijalnih rizika od prijenosa patogena; stoga bi svaki centar trebao prilagoditi medicinski razgovor svom sociokulturnom kontekstu kako bi bio učinkovitiji. Optimalni donor odgovara mladim osobama (po mogućnosti $<50$ godina), uzimajući u obzir da je sve veća dob povezana s promijenjenim sastavom mikrobiote crijeva; štoviše, ostarjela mikrobiota može imati negativan učinak pridonoseći upalnom stanju primatelja, iako je važno isključiti kandidate $\mathrm{s}$ osobnom anamnezom zloćudnih bolesti ili autoimunih bolesti. Štoviše, postoji zabrinutost zbog isključenja zdravstvenih radnika s obzirom na navodni povećani rizik od kolonizacije bakterijama otpornim na antibiotike; međutim, dostupni podaci sugeriraju nisku prevalenciju $\mathrm{u}$ ovoj populaciji. Potencijalni donori moraju se podvrći pregledu krvi i fekalija kako bi se isključila zarazna 
bolest koja se prenosi fekalnim prijenosom. Zapravo, ispitivanje krvi trebalo bi obuhvaćati kompletnu krvnu sliku, enzim jetre, kreatinin i C-reaktivni protein kako bi se provjerilo cjelokupno kliničko stanje, serologija za virus hepatitisa i virus humane imunodeficijencije

(HIV). Nadalje, testovi krvi mogu se uzeti u obzir u slučaju anomalija prvog kruga laboratorijskih testova, endemskog širenja nekih patogena, pojave novih patogena ili odabranih slučajeva primatelja (npr. imunosupresivnih). Ispitivanje stolice trebalo bi obuhvaćati uobičajene enteropatogene, Clostridium difficile, fekalne parazite i antigen Helicobacter pylori (ovaj posljednji ispit samo za gornji put davanja FMT-a). Nadalje, obvezno je testirati sve uzorke fekalija na bakterije otporne na antibiotike (uključujući Staphylococcus aureus otporan na meticilin (MRSA), enterokoke otporne na vankomicin (VRE), enterobacteriaceae koji proizvode $\beta$ laktamazu produženog spektra i enterobacteriaceae otporne na karbapenem / enterobacteriaceae koje proizvode karbapenemazu).

Danas, zbog nove pandemije Covid-19, panel međunarodnih stručnjaka predložio je da se u testove za Sars-CoV-2 uvrsti temeljiti bris nazofaringsa i / ili RNA u stolici. Konačno, ako su svi testovi krvi i fekalija negativni, kandidat se prihvaća da postane donor fecesa stolice. Osobito u programu fekalne banke, donor bi tijekom vremena trebao biti dostupan $\mathrm{u}$ mnogim prilikama. Iz tog razloga, poželjno je ponoviti probirne testove svakih osam do dvanaest tjedana i primijeniti kratki upitnik istog dana donacije kako bi se provjerilo ima li nedavnih štetnih događaja (Colman, 2014).

\subsection{3. Štetni učinci FMT-a}

Potencijalne nuspojave FMT-a mogu se kategorizirati na kratkoročne i dugoročne. Iako se kratkotrajni događaji također mogu razlikovati između nuspojava povezanih $\mathrm{s}$ putem primjene fecesa (nazogastrična sonda, kolonoskopija) ili samim FMT-om, postoji vrlo malo podataka o dugoročnim događajima s obzirom na nedostatak dužih budućih ispitivanja za procjenu njegove sigurnosti (Sunkara, 2018.).

\subsubsection{Kratkoročne nuspojave}

Bez obzira na način isporuke, česte nuspojave nakon FMT-a uključuju blagu groznicu i blage GI simptome (nelagoda u trbuhu, nadimanje, proljev, zatvor i povraćanje) koji se obično povuku za nekoliko tjedana. Čini se da put primjene utječe na sliku nuspojava. Na primjer, visoka temperatura $i$ porast C-reaktivnog proteina opisani su nazojejunalnim putem i rijetko su prijavljeni za aspiracijsku upalu pluća, dok su za kolonoskopiju opisani perforacija, krvarenje i učinci povezani s 
anestezijom. Zabilježena su dva slučaja crijevne infekcije (norovirus) 2 i 12 dana nakon FMT-a. U literaturi je zabilježen smrtni slučaj. Jedan slučaj opisao je slučaj aspiracije povezan s putem primjene FMT-a, dok je u drugom slučaju, bolesnik umro 13 dana nakon FMT-a uslijed progresivne upale pluća, zbog čega je bolesnik liječen antibioticima prije i nakon FMT-a. Međutim, potonji može biti nepovezan s FMT-om, već povezan $\mathrm{s}$ bolesnikovim komorbiditetom (Sunkara, 2018.).

\subsubsection{Dugotrajne nuspojave}

Glavna zabrinutost zbog sigurnosti FMT-a kod IBD-a je procjena dugoročnih nuspojava. Međutim, zbog nedostatka dugih prospektivnih studija, ne prikuplja se puno podataka o dugoročnim nuspojavama, a mnogi su špekulativni. Veliki teoretski rizik može biti izazivanje kroničnih bolesti na temelju promjene crijevne mikrobiote, što uključuje pretilost, dijabetes, aterosklerozu i rak debelog crijeva. Značajno debljanje zabilježeno je kod žene koja je primila FMT od donora prekomjerne tjelesne težine. Primatelj je također imao prekomjernu tjelesnu težinu $\mathrm{u}$ vrijeme FMT-a; stoga se podaci moraju tumačiti s oprezom. Konačno, dugoročno praćenje u kombinaciji s analizom pregledanih uzoraka dqonora i primatelja bit će presudno za procjenu sigurnosti i budućih štetnih događaja

(Sunkara, 2018.).

\subsubsection{Kontraindikacije za FMT}

Mnogi bolesnici i liječnici FMT često doživljavaju kao ,prirodni““ lijek, međutim, s obzirom na činjenicu da prijenos složene mikrobiote može modificirati fenotip domaćina s nepoznatim dugoročnim učincima,

poželjno je isključiti određene kategorije bolesnika kod kojih primjena FMT-a može pogoršati njihovo stanje ili čak biti fatalna. Primjerice, bolesnici s teškom bolesti crijeva ne mogu se podvrgnuti kolonoskopiji, dok su oni $\mathrm{s}$ ozbiljnom imunosupresijom i dekompenziranom cirozom jetre isključeni $\mathrm{s}$ obzirom na potencijalni rizik od prijenosa enteričnog mikroba iz donatorske stolice. Međutim, nedavno su Kelly i suradnici objavili retrospektivnu studiju imunokompromitiranih pacijenata koji su primali FMT za liječenje rCDI u kojem pokazuju da nije bilo zaraznih komplikacija nakon FMT-a u ovih potencijalno “rizičnih” bolesnika (Sunkara, 2018.).

\subsection{Iskustva u Republici Hrvatskoj}

FMT u Zagrebu urađen je u Kliničkoj bolnici Merkur 29. Svibnja 2020. godine po čemu je ta bolnica druga u zemlji koja predstavlja ovu metodu nakon Kliničkog bolničkog centra Rijeka, njihov prvi FMT bio je 2017. godie. Donor je bio nepoznat bolesnicima. Prvi bolesnik je bio na trećem ciklusu recidiva $C$. difficile, a drugi bolesnik na četvrtom. Tim 
liječnika i medicinskih sestara za gastroenterologiju i endoskopiju pripremili su bolesnike tekućom prehranom i dva seta MoviPrep praha, laksativne otopine koja potiče stolicu radi boljeg čišćenja, dan prije zahvata. MoviPrep ne predstavlja opasnost za dehidraciju jer sadrži minerale koji nadomještaju elektrolite koji se gube $u$ stolici. Oba bolesnika imala su periferni venski kateter u slučaju rijetkih nuspojava (perforacija crijeva ili tjelesna ozljeda) tijekom postupka ubrizgavanja tekućina, lijekova ili transfuzije krvi. FMT je kod oba bolesnika prošao dobro i bez ikakvih komplikacija ili nuspojava tijekom ili nakon zahvata. Uvidom u medicinsku literaturu, bolesnici su imali velika odstupanja u laboratorijskim pretragama (eukocitoza, visoki CRP, hipoalbuminemija) te izrazite promjene na crijevnoj sluznici uslijed recidivirajućih infekcija $C$. difficile. Kod jednog bolesnika postupak FMT je učinjen kao interevncija spašavanja života (prije nego se napravi kolonoskopija).

Bolesnici su nakon primijenjenog postupka FMT nastavljeni biti praćeni te se oporavljeni otpuštaju na kućnu njegu. FMT ima nespecifičnu prirodu liječenja, ali blagodati tog postupka su neosporive. U prilozima su fotografije liječničko-medicinskog tima endoskopije KB Merkur: medicinska sestra

\footnotetext{
${ }^{1}$ Zahvaljujem kolegici Ivoni Periša i docentici Ivani Mikolašević za nesebično dijeljenje informacija i fotografija o primjeni FMT.
}

Ivona Periša i docentica, Ivana Mikolašević prilikom zahvata FMT. ${ }^{1}$

\subsection{Budućnost terapijske upotrebe FMT-a}

Sve je veće prihvaćanje i prihvaćanje terapijske upotrebe FMT-a, djelomično zbog njegove percepcije kao 'prirodnog' liječenja i njegove relativno jeftine primjene. Unatoč takvoj percepciji, postoji strah od zaraznog potencijala terapije. Poduzeto je nekoliko dugoročnih studija za procjenu sigurnosti FMT-a, a teorijski rizik ostaje. To je vodilo istraživačkim skupinama da istraže upotrebu proizvoda 'sintetske stolice' $\mathrm{s}$ definiranim populacijama bakterija za ublažavanje takvih problema. Trenutno se ulažu napori na istraživanju uloge crijevne mikrobiote $u$ patofiziologiji mnogih drugih stanja, uključujući nekrotizirajući enterokolitis, bolesti jetre, rak debelog crijeva, adenokarcinom jednjaka i želuca te autizam. Uz to, promatranja bolesnika liječenih FMTom zbog funkcionalnih poremećaja crijeva primijetila su poboljšanje naizgled nepovezanih popratnih bolesti, otkrivajući moguću ulogu modifikacije crijeva i mikrobiote u mnogim drugim uvjetima. Ovisno o rezultatima tih ispitivanja, FMT se može smatrati potencijalno korisnom terapijom za dodatna stanja u budućnosti. 
Klinička ispitivanja koja su u tijeku i dalje će pružati uvid u ovo rastuće područje (Gupta, 2016). Kako bi FMT napravio još veći i učinkovitiji napredak u medicini, potrebna je češća upotreba, razna iskustva u primjeni i usporedbe. U Republici Hrvatskoj ne postoji

kampanja doniranja fecesa, za sad su donori medicinski studenti volonteri. Ipak, u svijetu je prepoznata važnost FMT te se mogu naći razne kampanje doniranja fecesa, koje naglašavaju strogo tko može biti donor, a nerijetko su i potkrijepljene novčanom nagradom.

\section{ZAKLJUČAK}

Metoda fekalne transplantacije mikrobiote jedna je od važnijih novijih pristupa liječenju infekcije s Clostridium difficile bakterijom. Pojavnost tih infekcija u novije je vrijeme sve značajnija, posebno u bolničkom okruženju, jer se pojavljuju mutirani sojevi te bakterije koji su otporni na antibiotike i mogu uzrokovati ozbiljne probleme. Analiza literature na ovu temu pokazala je kako je nužno obratiti pažnju na podizanje svijesti o prisutnosti te bakterije, ali i na prevenciju putem izolacije zaraženih pacijenata, održavanja i provođenja higijene ruku itd. Ovdje je nužno napomenuti kako sve popularnija metoda pranja ruku preparatima na bazi alkohola koji pomažu dezinfekciji nije rješenje kad se radi o infekcijama bakterijom C. difficile jer je ta bakterija otporna na alkohol pa se stoga $\mathrm{u}$ literaturi sugerira pranje ruku vodom i sapunom kao jedina sigurna mjera prevencije u bolničkom okruženju. Pozitivno gledište na taj problem daje činjenica kako se većina infekcija tom bakterijom otklanja vrlo rano te $\mathrm{u}$ većini slučajeva nije nužna intervencija koja bi zahtijevala nekonzervativno liječenje. U slučajevima kod kojih se liječenje ne može provesti antibioticima, nova metoda liječenja koja se pokazala izrazito uspješnom je fekalna transplantacija mikrobiote. Kod fekalne transplantacije riječ je o transplantaciji mikrobiote zdravoga donora, najčešće putem kolonoskopije, bolesniku koji boluje od infekcije $\mathrm{s} C$. difficile. Studije koje su analizirane tim radom pokazale su kako je fekalna transplantacija metoda izbora osobito kod pacijenata koji imaju recidiv infekcije $\mathrm{s}$ bakterijom $C$. difficile gdje primjena te metode $\mathrm{u}$ visokom postotku dovodi do smanjenja recidiva infekcije. Noviji istraživački radovi pokazuju i kako se liječenje sa super pročišćenim sadržajem stolice, tzv. „superprobiotikom“ može smatrati sljedećim korakom u fekalnoj transplantaciji s obzirom da takav sadržaj zamjenjuje suspenziju stolice koja se, primjenjuje u klasičnoj fekalnoj transplantaciji. To se može smatrati samo nastavkom evolucije u primjeni mikrobiote $u$ liječenju koje je čovječanstvu poznato gotovo onoliko koliko je i samo staro. Još uvijek ne znamo dovoljno o svim utjecajima crijevne mikrobiote jer ona zbog svoje složenosti može 
Nastavnička revija 2 (2021) 1, 47-67

utjecati na mnoštvo fizioloških funkcija, uključujući metabolizam, imunitet i neurološki razvoj te da ima još dosta neodgovorenih pitanja, koja se odnose na probir i odabir davatelja, standardizirane protokole i dugoročnu sigurnost. Fekalna mikrobiota je jedan od najvažnijih alata personaliziranog pristupa bolesniku jer prirodni transfer mikrobiote zdravog davatelja bolesniku može donijeti dugoročnu izlječivost od bolesti te poboljšati ukupnu kvalitetu života, a daljnje mogućnosti razvoja ove metode otvaraju prostor još boljoj i učinkovitijoj primjeni u budućnosti. Zbog toga je potrebno provesti daljnja istraživanja $u$ pogledu fekalne transplantacije u odnosu na odabir donora kroz usporedbu standardnih baza donora u odnosu na donore iz bolesnikove neposredne okoline što se danas najčešće koristi, te standardizacije pripremnih tehnika i općenito poboljšanje dugoročne sigurnosti i efikasnosti fekalnih transplantacija. Ovim se radom željelo pokazati kako može biti pozitivan utjecaj fekalnih transplantacija na bolesnike zaražene bakterijom $C$. difficile s osvrtom na prirodu te bakterije, njen utjecaj unutar bolničkog okruženja i sve veću pojavnost infekcija. Fekalna transplantacija tu se pokazala kao metoda izbora za smanjenje recidivizma infekcije, ali kao potencijalna buduća metoda izbora koja bi mogla imati prednost u odnosu na danas primjenjivane antibiotike, a $\mathrm{s}$ obzirom na sve veći rast rezistencije.

Fekalne transplantacije treba gledati kao logični korak naprijed $\mathrm{u}$ tretiranju te vrste infekcija, ali i kao zatvaranje kruga u odnosu na prve ideje o liječenju mikrobiotom koje su stare više od tisuću godina.

\section{LITERATURA}

1. Bartlett, J. G. 2008. Clinical recognition and diagnosis of Clostridium difficile infection. https://pubmed.ncbi.nlm.nih.gov/18177217/ (pristupljeno 22 travnja 2021.)

2. Colman, R. J. 2014. Fecal microbiota transplantation as therapy for inflammatory bowel disease: a systematic review and metaanalysis.

https://pubmed.ncbi.nlm.nih.gov/25223604/

(pristupljeno 22. travnja 2021.).

\section{CJI Infektološki glasnik, 2018.}

\section{CLOSTRIDIOIDES difficile.}

https://cji.com.hr/clostridium-difficille/

(pristupljeno 22. travnja 2021.).

4. Joksimović, Z. i sur., Clostridium difficile infekcija: prikaz novih saznanja. Glasilo Podružnice Srpskog lekarskog društva Zaječar. 2013., sv. 38, 1.

5. Gupta, S. 2016. Fecal microbiota transplantation: in perspective.

https://www.ncbi.nlm.nih.gov/pmc/articles/P MC4749851/ (pristupljeno 19. travnja 2021.). 6. Khoruts, A. 2017. Fecal microbiota transplantation-early steps on a long journey ahead.https://www.ncbi.nlm.nih.gov/pmc/artic les/PMC5479406/ (pristupljano 21. travnja 2021.)

7. New Clostridium difficile Guidelines.

SHEA The Society for Healthcare 
A.Krkić Drobić, Fekalna transplantacija

Epidemiology of America. https://shea-

online.org/index.php/journal-news/website-

highlights/572-new-clostridium-difficile-

guidelines (pristupljeno 22. travnja 2021.)

8. Pajić. A. 2017. Ljudska mikrobiota: funkcija, modulacija mikrobiote u kliničkim ispitivanjima i implementacija u praksi. Završni specijalistički. Sveučilište u Zagrebu. Farmaceutsko - biokemijski fakultet. (pristupljeno 21. travnja 2021.). https://urn.nsk.hr/urn:nbn:hr:163:861948.

10. Rogers, G. B. 2013. Challenges and opportunities for faecal microbiota transplantation therapy

https://www.cambridge.org/core/journals/epid emiology-and-infection/article/challengesand-opportunities-for-faecal-microbiotatransplantationtherapy/906AACF9D31ECFD BB75E8A2C529FF57A (pristupljeno 21. travnja 2021.)

11. Thomas, D. L. 2021. History of Fecal Transplant. https://www.newsmedical.net/health/History-of-Fecal-
Transplant.aspx (pristupljeno 21. travnja 2021.).

12. Qin, J. 2010. A human gut microbial gene catalog established by metagenomic sequencing.https://www.ncbi.nlm.nih.gov/pm c/articles/PMC3779803/ (pristupljeno 19. travnja 2021.).

13. Tuddenham, S. 2015. The Intestinal Microbiome and Health https://www.ncbi.nlm.nih.gov/pmc/articles/P MC4643846/ (pristupljeno 21. travnja 2021.) 14. Štimac, D. Fekalna transplantacija transfer fekalne makrobiote. Sveučilište $u$ Rijeci, Medicinski fakultet, Klinički bolnički centar Rijeka, Klinika za internu medicinu, Zavod za gastroenterologiju, Rijeka, Hrvatska. Acta Medica Croatica, 73 (2019.) 79-80. 15. Šušnjar, L. 2019. Fekalna transplantacija. Završni rad. Sveučilište u Rijeci. Fakultet zdravstvenih studija. Preddiplomski sveučilišni studij sestrinstva.

\section{SKRAĆENICE KORIŠTENE U RADU}

$\mathrm{CD}$ - Clostridium difficile

CDI - infekcija C. difficile; eng. Clostridium difficile infections

rCDI - ponavljajuća infekcija $C$. difficile; eng. Clostridium difficile infections recidivans

AAD - proljev uzrokovan upotrebom antibiotika; eng. Antibiotic-associated diarrhea

IBD - upalna bolest crijeva; eng. Inflammatory bowel disease

UC - ulcerozni kolitis

IBS - sindrom iritabilnog crijeva; eng. Irritable Bowel Syndrome 
GIT - gastrointestinalni trakt

ChD-Chronova bolest; eng. Chron Disease

FGID - funkcionalni gastrointestinalni poremećaji; eng. Functional Gastrointestinal Disorders

PMC - pseudomembranozni kolitis

FMT - fekalna transplantacija mikrobiote; eng. Fecal Microbiota Transplant

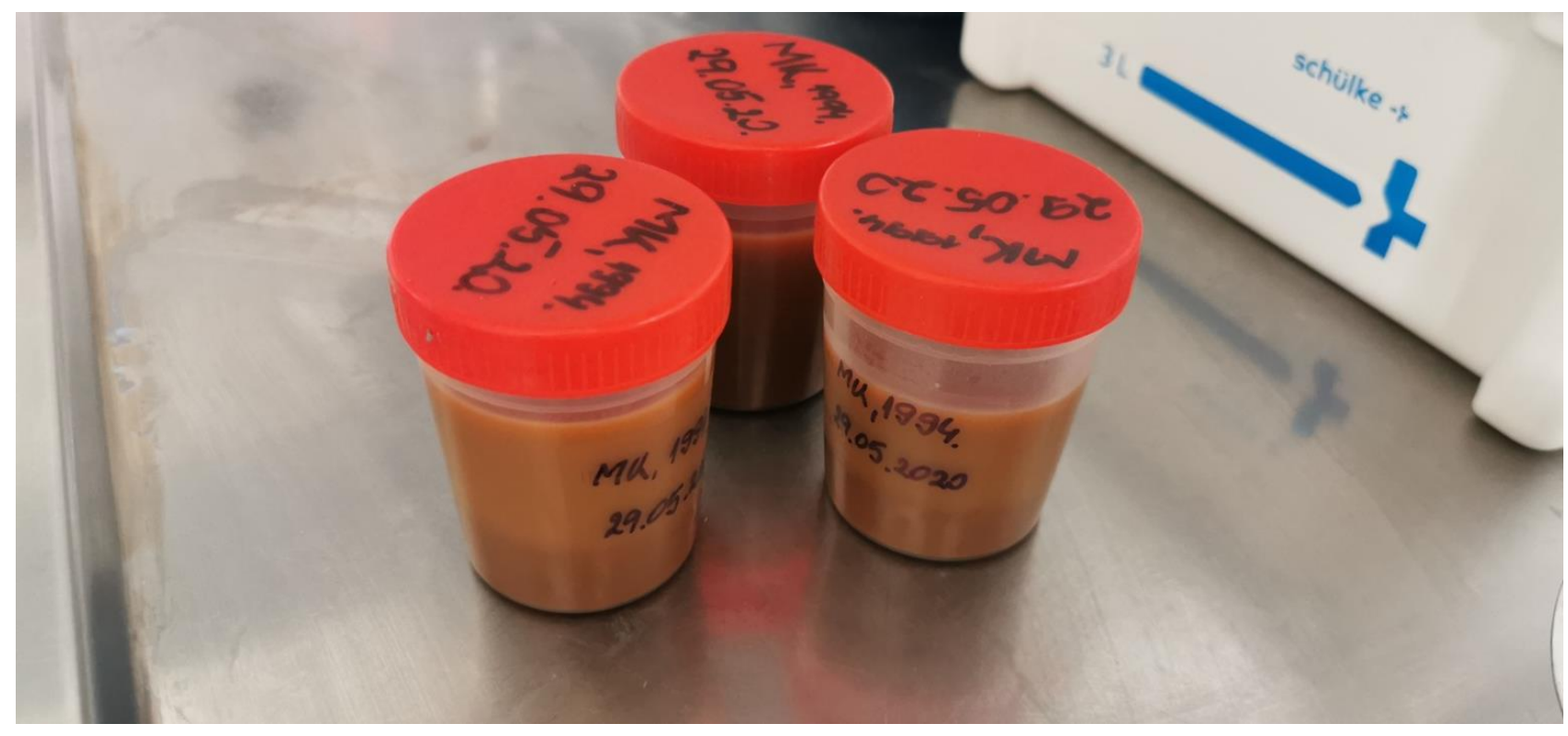

Slika 1. Uzorci fecesa

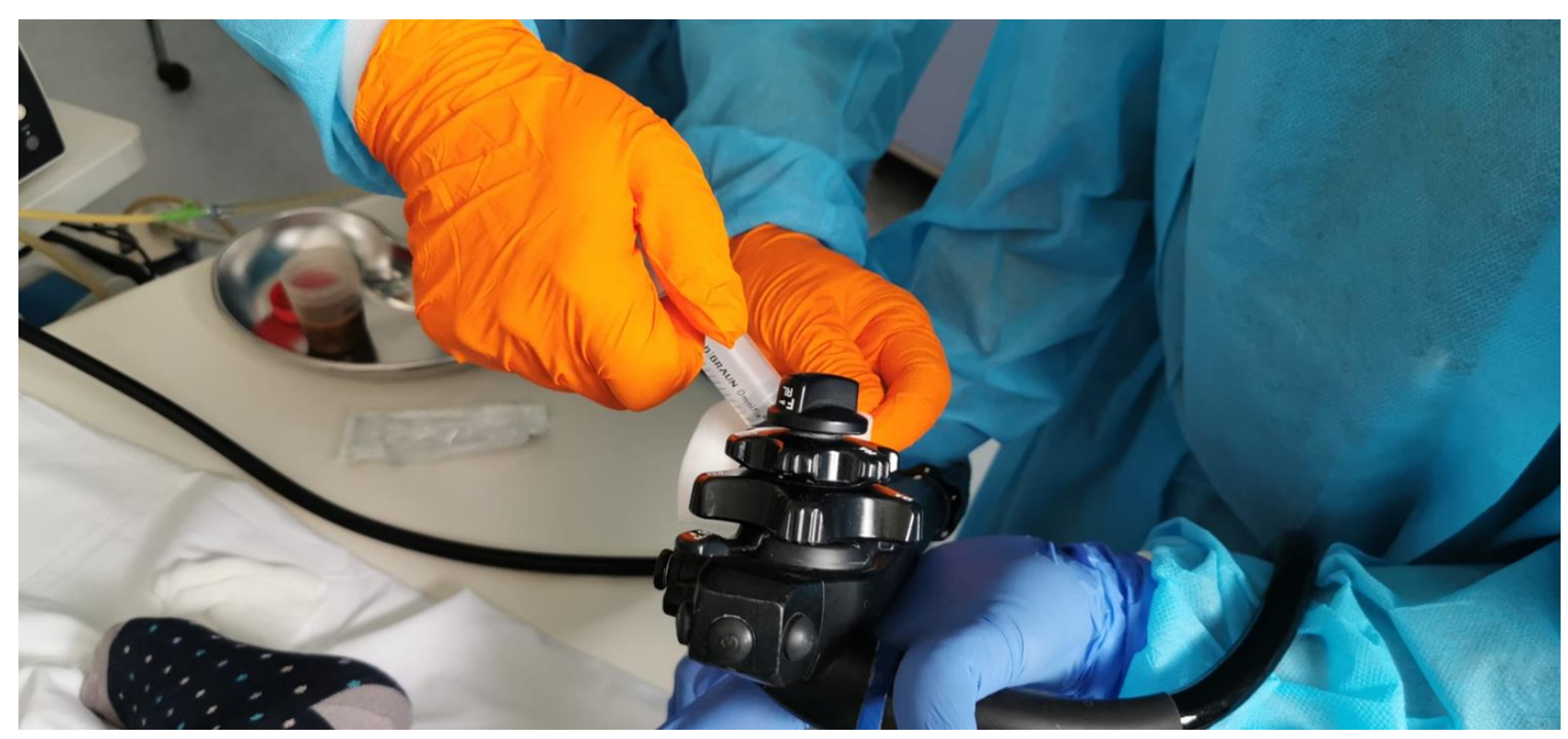

Slika 3. Zadovoljstvo zdravstvenih djelatnika uspješnim izvođenjem FMT 
A.Krkić Drobić, Fekalna transplantacija

Slika 2. Postupak aplikacije fecesa u endoskop

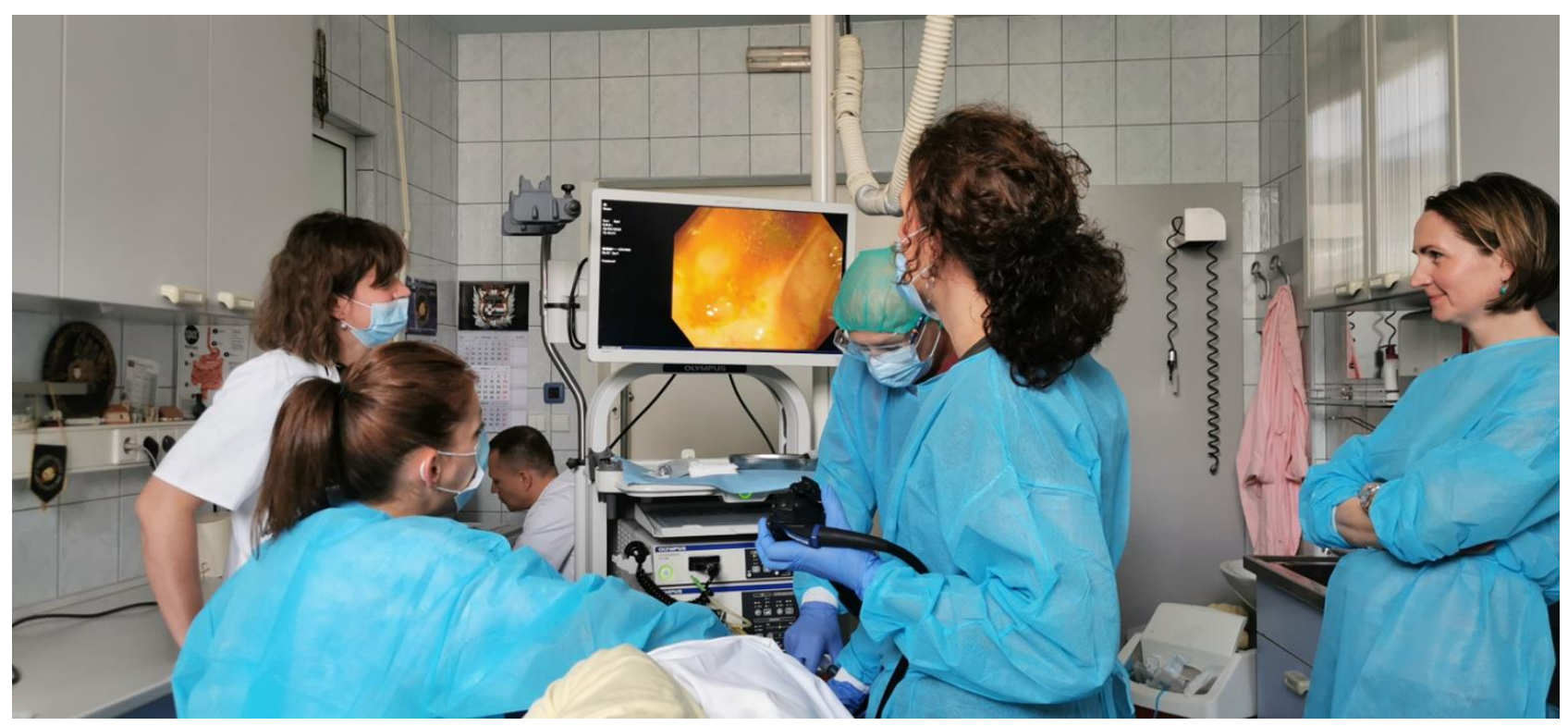

Slika 3. Tim liječnika i medicinskih sestara u postupku FMT pod kontrolom endoskopa

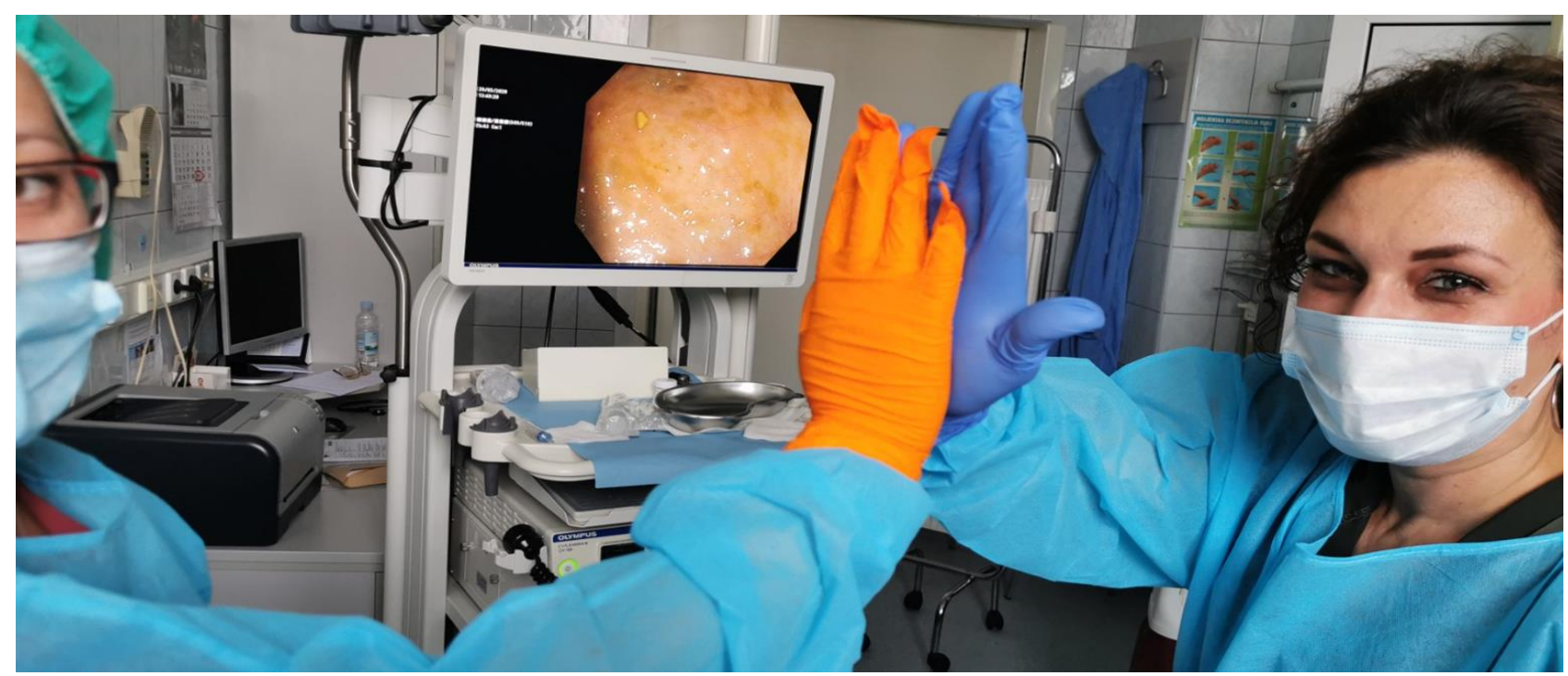

Slika 4. Zadovoljstvo zdravstvenih djelatnika uspješnim izvođenjem FMT 


\section{SUMMARY}

\section{FECAL TRANSPLANT}

Fecal Microbiota Transplant (FMT) is the process of transplanting an infusion of bacteria from the stool of a healthy donor to a recipient with a disease believed to be associated with an unhealthy intestinal microbiome. The intake of encapsulated bacteria of a healthy person is performed by endoscope, nasogastric tube or orally via a capsule. This approach is quite successful for treating infections caused by the bacterium Clostridium difficile which causes lifethreatening diarrhea. It has been found in the literature that compatibility between donors and recipients is much more important than currently thought, so with such an approach, the use of FMT would probably be successful in the treatment of other intestinal diseases. Donor and recipient "bacterial" compatibility has been shown to be extremely important - a single donor transplant had different effects in three different patients. To minimize the risk of infection or transmission of another disease, potential donors undergo rigorous screening, including thorough history taking, serological tests, and fecal tests for parasitic, virological, and bacterial pathogens. Although there are some differences between institutions, there are existing accepted protocols for donor screening. With stool banks providing universal fecal material for use, which is highly reviewed and cataloged, barriers such as cost and availability can be overcome, allowing research and treatment to be simplified. In addition, with the advent of the FMT capsule, it can occur with improved convenience, reduced patient reluctance, and simplified procedural preparation. In order to maintain patient safety and the appropriate use of FMT, standardized protocols for donor screening, stool preparation, delivery methods, and recipient indications for treatment are expected to emerge.

Key words: Fecal microbiota transplantation, Clostridium difficile infection, colonoscopy. 